\title{
Vlog: the Mean to Improve Students' Speaking Ability
}

\author{
Izzah Maulidah \\ Language Center \\ Muhammadiyah University of Gresik \\ Gresik, Indonesia \\ newizzahmaulidah@gmail.com
}

\begin{abstract}
Technology and social media are great combination for English learning process since they provide a chance to improve students' ability in English. A lot of media can be used to facilitate it and one of them is vlog. It is the mean to increase students' speaking ability. This paper is aimed at exploring these three terms; a) Vlog and its tools, b) Vlogging stages, and c) Significances of it in improving students' speaking ability. By supporting Vlog with a sophisticated vlogging stages and a proper scoring reflection as a feedback, it is expected to improve students' speaking ability in English.
\end{abstract}

Keywords-Technology; Social Media; Vlog; Students speaking ability

\section{INTRODUCTION}

Nowadays, technology took a role as a mean of learning English in which it is in the form of software or hardware. vlog is one of technology in software form which is currently used by teacher to increase students' performance, especially in speaking. Several studies have promoted the phenomena that vlog can effectively facilitate language teaching and learning [1], especially in terms of "learners' language complexity, grammatical correctness, and fluency" [2]. However, the existence of vlog as one of latest technology is really expected to improve students' speaking ability in learning English.

Dealing with this, there are some significances fulfilled when vlog is implemented. First, it will build high self efficacy of students by having social media and technology in learning process. Several studies found that vlogging is an effective tool to develop teaching selfefficacy ([3]; [4]). Second, students of EFL will get semireal activity in using English in which it is little bit limited. The last, the notion increases students' English talk time that is definitely expected to improve students' speaking ability [5]. Those are some meanings of vlogging application.

Regarding all the benefit of this notion, this study is aimed at providing a theoritical and library research on how vlogging can be used as a mean to improve students' speaking ability. The focuses are; a) terms of vlogging and its practical tools, b) vlogging stages, and c) the significances of it in improving students' speaking ability. It will be described in the following discussion.

\section{DISCUSSION}

Board of discussion will bring the reader to comprehend the concept of vlog and practical view to implement it in the class. The more information related to it will be elaborated as follows:

\section{A. $\quad$ Vlog}

In this era, Computer Mediated Communication (CMC) can be used to encourage students in obtaining the goal of learning that is "effective language learning" meaningfully [6]. One of the best feature from CMC is the existence of web-blogging in which it provides the application of vlog. The existence of it can facilitate students to reach the goal of learning.

Vlog defines as the video component [7] that provides a series of online broadcasts [8] which is allowing everyone to create and post content [9] and considers it as video collections that serve both as an audiovisual life documentary and as a vehicle for communication. In addition, reference [10] define it as a site in which authors post stories and or information about certain topic in the form of video. A vlog is a portmanteau of the words video and blog (blog stands for web and $\log$ ).

When students have completed their videos, they start to find a way to share them with the teacher and / or the class. A number of websites could be considered to host the videos. Those are YouTube.com, Facebook, MailVu.com, Dropbox and another internet website.

The most famous online video hosting site is YouTube.com. Students are really familiar with it. It is relatively easy activities in which students can make an account and upload a video. Another video hosting option is Facebook. Some teachers might be worry about having Facebook friends with students (also vice versa). Teachers can create a private Facebook group for each class, so that the class members can see the contents. Other options such as MailVu.com, Dropbox and etc also have specific service terms to provide vlogging.

\section{B. Vlogging Stages}

Reference [10] claims there are several stages in Vlogging activity which is found in his research. Every stages has 
their own purpose and certain lists of activity. This table will summarize all the stages.

\begin{tabular}{|c|c|}
\hline Vlogging stages & Activities \\
\hline Conceptualizing & $\begin{array}{l}\text { 1. Planning what to say and how to say it } \\
\text { 2. Coming up with an appropriate voice- } \\
\text { blog topic } \\
\text { 3. Listening to others' vlogs for ideas } \\
\text { 4. Consulting a dictionary or searching the } \\
\text { Internet } \\
\text { 5. Note-taking }\end{array}$ \\
\hline Brainstorming & $\begin{array}{l}\text { 1. Outlining main and supporting ideas } \\
\text { 2. Translating from L1 to L2 } \\
\text { 3. Writing down a script before recording }\end{array}$ \\
\hline Articulation & $\begin{array}{l}\text { 1. Rehearsing before recording } \\
\text { 2. Recording voice blog and uploading it } \\
\text { after checking }\end{array}$ \\
\hline Monitoring & $\begin{array}{l}\text { 1. Listening to the recorded file before } \\
\text { uploading it } \\
\text { 2. Monitoring vlog entries in terms of } \\
\text { content, organization, and language usage }\end{array}$ \\
\hline Evaluating & $\begin{array}{l}\text { 1. Evaluating vlog content, organization, } \\
\text { and language-usage } \\
\text { 2. Redoing the vlogs }\end{array}$ \\
\hline
\end{tabular}

Table 1. Vlogging Stages

\section{1) Conceptualizing}

The first stage is conceptualizing in which it is involved in making plan of vlogs. Reference [10] in his research found that the most difficult things faced by the students is when they tried to decide a certain topic. Reference [5] claims that it will be effective if the teacher provides several topics or question as options for students before making vlog. Some examples can be:

- Ageneral self-introduction

- A how-to demonstration of something the student is good at or a meal he or she is skilled at preparing

- An interview (and simultaneous translation) of an L1 friend or family member

- An introduction of a pet

- A trip to a favorite neighborhood place (if the student is using a smart phone or laptop)

- Anything related to content being discussed in class, or a reaction to assigned reading

\section{2) Brainstorming}

In Brainstorming stage, students begin to create the concept of vlog; what they want to say in the video. They make a script and translate it from host language (Bahasa Indonesia) to target language (English). It is the continuity of previous stage with practical result and it is guided by a certain topic.

\section{3) Articulation}

In other words, we may call articulation as action in which students do rehearsal before starting to shoot their speaking activities. Somehow, it is possible to make editing for the video before uploading. They may also insert a picture, song, words or any others which can make the video become more interesting. Therefore, in this stage, they really express their creativity and speaking ability.

\section{4) Monitoring}

Both monitoring and articulation are seemingly done together. Before uploading the video, students need to check the content of the video, whether or not it is suitable and already covered the rubric score given by the teacher. When it is finished; uploading is done, students monitor the video again to check it.

\section{5) Evaluating}

In this stage, the students do activity as selfcorrection related to their project. They may also ask their friends to give an opinion about it. If they found mistakes in terms of meaning, form or etc, they may redo a vlogging.

The framework of Vlogging can be visualized in Figure 1. All stages including conceptualization; making plan, brainstorming; drilling and designing, articulation; rehearsal and shooting, monitoring; checking, and evaluating; self-correction snd redoing. They are united in one activity namely vlogging.

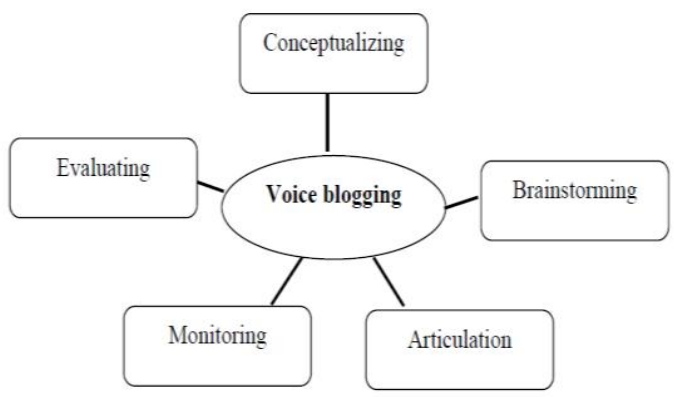

Figure 1. Framework of Vlogging

Before coming up with the stages, teacher may also give the students a score reflection. It will measure the proficiency area of vlog's content. The criteria can be in the form of questions which reflects students' project as the answer. [5] provides this as the example: 


\begin{tabular}{|l|l|}
\hline $\begin{array}{l}\text { Proficiency } \\
\text { Area }\end{array}$ & Evaluative Criteria \\
\hline Vocabulary & $\begin{array}{l}\text { - Is the student using correct and appropriate word choices? } \\
\text { - Should the student employ vacabulary more suitable for an academic } \\
\text { audience? }\end{array}$ \\
\hline Grammar & $\begin{array}{l}\text { - Is the student making progress with grammar usage? } \\
\text { - Do the same grammar mistakes keep happening? } \\
\text { - Do grammar mistakes lead to problems discerning meaning? }\end{array}$ \\
\hline Pronunciation & $\begin{array}{l}\text { - Is the student making consistent and predictable pronunciation errors? } \\
\text { - Do these pronunciation errors make it difficult to understand what the } \\
\text { student is talking about? }\end{array}$ \\
\hline Fluency & $\begin{array}{l}\text { - Is the student talking smoothly and confidently, or is the speech interrupted } \\
\text { by long, awkward pauses? } \\
\text { - Was the speech extemporaneous or obviously read from a manuscript? }\end{array}$ \\
\hline Content & $\begin{array}{l}\text { - Did the student talk for the requested amount of time? } \\
\text { - If the vlog assignment requested reflection on a certain theme or action in } \\
\text { accordance with a set of directions, did the student make efforts to address } \\
\text { this theme and / or follow directions? }\end{array}$ \\
\hline
\end{tabular}

Table 2. Example of Scoring Reflection

This reflection will help students to consider and pay attention to several aspects mentioned as criteria before creating a vlog. Teacher allows to modify it by providing the level of capability and/or the proficiency. Other example of assessment rubric is designed by Moya. Here is the rubric:

\begin{tabular}{|c|c|c|c|c|}
\hline & Excellent & Good & Average & Poor \\
\hline Pronunciation & $\begin{array}{l}\text { There are no } \\
\text { pronunciation } \\
\text { mistakes. }\end{array}$ & $\begin{array}{l}\text { There are few } \\
\text { pronunciation } \\
\text { mistakes. }\end{array}$ & $\begin{array}{l}\text { There are } \\
\text { some } \\
\text { pronunciation } \\
\text { mistakes. }\end{array}$ & $\begin{array}{l}\text { The oral message } \\
\text { is } \\
\text { incomprehensible. }\end{array}$ \\
\hline Stress & $\begin{array}{l}\text { The student } \\
\text { masters stress } \\
\text { perfectly. }\end{array}$ & $\begin{array}{l}\text { The students } \\
\text { makes few } \\
\text { stress } \\
\text { mistakes. }\end{array}$ & $\begin{array}{l}\text { There are } \\
\text { some mistakes } \\
\text { related to } \\
\text { stress. }\end{array}$ & $\begin{array}{l}\text { The student does } \\
\text { not stress any } \\
\text { syllables } \\
\text { correctly. }\end{array}$ \\
\hline Intonation & $\begin{array}{l}\text { The student's } \\
\text { intonation is } \\
\text { perfect. }\end{array}$ & $\begin{array}{l}\text { The student's } \\
\text { intonation has } \\
\text { few mistakes. }\end{array}$ & $\begin{array}{l}\text { The student } \\
\text { makes some } \\
\text { intonation } \\
\text { mistakes. }\end{array}$ & $\begin{array}{l}\text { The intonation is } \\
\text { not correct. }\end{array}$ \\
\hline $\begin{array}{c}\text { Interest and } \\
\text { motivation }\end{array}$ & $\begin{array}{l}\text { The student is } \\
\text { highly } \\
\text { motivated. }\end{array}$ & $\begin{array}{l}\text { The student is } \\
\text { often } \\
\text { motivated. }\end{array}$ & $\begin{array}{l}\text { The student is } \\
\text { not always } \\
\text { motivated. }\end{array}$ & $\begin{array}{l}\text { The student does } \\
\text { not show any } \\
\text { interest. }\end{array}$ \\
\hline Evolution & $\begin{array}{l}\text { The student } \\
\text { has clearly } \\
\text { acquired new } \\
\text { knowledge. }\end{array}$ & $\begin{array}{l}\text { The student } \\
\text { has learnt } \\
\text { some new } \\
\text { contents but } \\
\text { not all of them. }\end{array}$ & $\begin{array}{l}\text { The student } \\
\text { has acquired } \\
\text { little } \\
\text { knowledge. }\end{array}$ & $\begin{array}{l}\text { The acquisition of } \\
\text { knowledge is not } \\
\text { enough. }\end{array}$ \\
\hline Participation & $\begin{array}{l}\text { The student } \\
\text { participates } \\
\text { both in class } \\
\text { and on the } \\
\text { blog. }\end{array}$ & $\begin{array}{l}\text { The student } \\
\text { often } \\
\text { participates in } \\
\text { class or on the } \\
\text { blog. }\end{array}$ & $\begin{array}{l}\text { The student } \\
\text { does not } \\
\text { participate in } \\
\text { class or on the } \\
\text { blog. }\end{array}$ & $\begin{array}{l}\text { The student does } \\
\text { not participate. }\end{array}$ \\
\hline
\end{tabular}

Table 3. Assessment rubric

The rubric describes the levels of proficiency criteria; excellent, good, average, poor. The purpose of confirming the rubric to sudents is in order to make them be motivated to create a good vlog covering those criteria. The focus of the rubric is in speaking skill, such as pronunciation, stress and intonation. Moreover, the value of class process is also assessed in the rubric; interest and motivation, evolution or progess, and participation.

\section{The Significance(s) of Using Vlog in Students' Speaking Improvement}

Taking into account the process of vlogging, there are some significances that can be obtained as the positive impact of it. [10] claims several significances as impact of vlogging. Those are;

\section{1) Students'Encouragement}

Vlog will increase students' encouragement in speaking. The role of Vlog is also as social media consumption that is really common used by students in their daily activity. They prefer to use it to express their ideas, feelings and improvisation. Moreover, the easiness in operating it also supports their willingness to use in their project, especially fulfilling speaking task. When students feel easy in finishing their project, automatically, they will be also motivated. Vlog covers those two things.Thus, it has significant impact in increasing students' encouragement.

\section{2) Self Presentation}

Vlogging has close relation with the use of social media. It impacts pshycologically to students when they prepare their performance. They will perform their best presentation in their vlog. Consequently, the use of vlog significantly improve students' self presentation especially in their speaking performance.

\section{3) Talk More Time}

EFL students have limited chance to express their speaking performance. Students only practice their English speaking in the class or special event that used English as tool of communication. By providing vlog as one of teaching media, students will get more chance to talk outside the class. Vlogging force them to talk and tell their ideas in English. As the result, their speaking ability will increase gradually.

\section{4) Autonomous Learning}

Task based learning provides autonomousity for students. Vlogging is also one of strategy in task based learning. One of benefit in autonomous learning, students will get their meaningfulness in their study. In addition, they are free to manage their ideas related to their learning process. Vlogging covers this condition and bring the students in autonomous learning.

Vlogging is one innovation to provide a better teaching learning process especially in speaking. The corelation with technology and social media makes it really fun to be implemented for students. Some modification in vlogging stages is possible for teacher. It depends on the condition of the class. Whether the possibility of 
difficultness in practical aspect could be there, but this notion is still good to be considered as teaching media. Finally, vlogging will sophistically increase the ability of students in speaking.

\section{CONCLUSION}

Finally, Vlog significantly improves students' speaking ability. It can boost students' encouragement by providing fun and accesable learning process. In addition, it promotes good presentation in students' speaking performance. They will be able to interact in authentic environment to get a lot of exposure in speaking. In addition, students get a chance to build up their autonomous learning. Those several things bring students to enhance their progress in speaking ability.

For further discussion, the role of vlogs as media of teaching with its practical concept such approach used or techniques implemented can be interesting. Others, content analysis on vlog project result in terms of language used by the students which errors or pattern may be found is also brilliant. The discussion of vlogs is still warm and it has wide room to debate in the way of process and its existence as the media of learning.

\section{REFERENCES}

[1] Bloch, J., and Abdullah's blogging: A generation 1.5 student enters the blogosphere. Language Learning \& Technology, 11(2), 2007, 128-141. Retrieved March 14, 2008, from http://lit.msu.edu/vol11num2 /bloch/default.html.

[2] Hewett, B., Characteristics of interactive oral and computer-mediated peer group talk and its influence on revision. Computers and Composition, 17(3), 2000, 265-288.

[3] Avci, U. \& Askar, P., The comparison of the opinions of the university students on the usage of blog \& wiki for their courses. Educational Technology \& Society, 15(2), 2012, 194-205.

[4] Stevens, T. \& Harris, G., Developing Teachers' Mathematics Knowledge for Teaching: Challenges in the Implementation \& Sustainability of a New MSP. Paper presented at MSP LNC Conference, Washington D.C., January 24-26, 2010.

[5] Watkins, Jon., Increasing Student Talk Time through Vlogging. Language Education in Asia, 2012, 3(2), 2012, 196-203. Retrieved at 9 th 2017 January from http://dx.doi.org/10.5746/LEiA/12/V3/I2/A08/Watkins

[6] Meskill, C., \& Ranglova, K., Socio collaborative language learning in Bulgaria. M. Warschauer \& R. Kern (Eds.), Network-based language teaching: Concepts and practice (pp. 20-40). New York: Cambridge University Press. 2000.

[7] Gunelius, S., Blogging all-in-one for dummies, $2^{\text {nd }}$ Ed, New Jersey: John Wiley \& Sons, 2012.

[8] Molyneaux, H., Gibson, K., O'Donnell, S. \& Singer, J., New visual media \& gender: A content, visual \& audience analysis of YouTube vlogs. Paper presented at the International Communication Association Annual Conference, Montreal, Quebec, Canada, May 2226, 2008.

[9] Biel, J. \& Gatica-Perez, D., Voices of vlogging. Paper presented at the $4^{\text {th }}$ International AAAI Conference on Weblogs \& Social Media, Washington, DC, May 23-26, 2010.

[10] Sun, Yu-Chih., Voice Blog: An Exploratory Study Of Language Learning. Language Learning \& Technology. June 2009, Volume 13, No. 2, 2009, pp. 88-103 